\title{
AC 2010-43: THE RAPID DEVELOPMENT OF COMPUTER SCIENCE AND INFORMATION AND COMMUNICATIONTECHNOLOGY (ICT) COURSES AT HIGHER EDUCATION INSTITUTIONS IN AFGHANISTAN
}

\section{Bahawodin Baha, University of Brighton}

Dr Baha is a Principal Lecturer at the Faculty of Science and Engineering, University of Brighton, England. Following his graduation from Kabul University (KU) in 1980, he was an assistant lecturer at KU for a while. Then he was able to obtain a British Council Scholarship and has completed his MSc and PhD degrees at the Universities of Salford and Brighton respectively. He has been teaching at the University of Brighton since 1989, where he has been teaching and conducting research in electronics. He has published many papers on power electronics at high quality international journals and conferences.

In addition to his duties at University of Brighton, he has been helping the higher education sector in Afghanistan for the last six years. He is conducting several DFID/British Council and the World Bank funded projects in Afghanistan. He has prepared several reports for the Afghan government and has published many papers at international conferences on how to improve technical vocational and engineering education in Afghanistan.

He was a visiting scholar at Virginia Polytechnic, Institute and Sate University in the USA in $1991-1992$.

\section{Ogai Ahmadi, Kabul University}

Ogai Ahmadi is an assistant lecturer at the Faculty of Computer Science, Kabul University (KU), Afghanistan. She received her BS from Kabul University and was chosen on merit to be appointed as an assistant lecturer, and she was subsequently sent to Germany in order to complete her master degree in Computer Science and IT at Technical University of Berlin. She is due to complete her MSc in March 2010 and then will return back to KU to continue her duties at KU. She has conducted several presentations in Afghanistan and Germany about the progress of computer science and IT in Afghanistan for the last few years. 


\section{The rapid development of Computer Science and Information and communication Technology (ICT) courses at higher education institutions in Afghanistan}

Abstract

The development of computer science and ICT courses within the higher education institutions in Afghanistan has been discussed in this paper and the main reasons behind such success have been highlighted. Recommendations have been made to integrate ICT within mainstream education and to improve and develop the education of other science, engineering and technology subjects within the Afghan universities, which will be crucial for future development in the country.

\section{Introduction}

Science, Engineering and Technology have truly revolutionized people lives and there is no doubt that the advancement of science and technology has improved the quality of life in the developed world. The dramatic progress in engineering technologies during the 1980s and 1990s brought prosperity and better economic conditions to the society and thus, the development in technologies has made a huge contribution to improve the standard of life across the world. Examples of such technologies are computer technology, IT, digital communications and information and communication technology (ICT). Higher education in the above subjects across the world has played an important role to develop these technologies. However, the people of Afghanistan has regrettably not benefited from these golden opportunities because of wars and instabilities in the country. Higher education institutions in Afghanistan have been devastated because of decades of wars, neglect and instability. Improving the education system, specifically in subjects related to science and technology, is crucial for the future development in the country. Afghanistan had a reasonable education system in the region [1] and amongst the education institutions; specific attention had been made to improve the overall education system specifically in subjects related to science and engineering [2] - [3]. Regrettably, the progress that was achieved in 1970's has been reversed because of the decades of wars and instabilities.

Limited progress has been achieved since the establishment of new government over seven years ago. For instance the number of students has increased, some new institutions have been established and effort has been made to upgrade the experience and qualifications of existing 
academics in such institutions. However, the overall quality of higher education has not been improved significantly, the exception being that the computer science and information technology (IT) sector has experienced substantial progress and expansion in the country.

This paper will present the history of computer science and IT courses and their rapid development throughout universities and other higher education institutions in Afghanistan. The paper will also examine the main reasons behind the accomplishment and the successful expansion of computer science and IT courses compared to traditional engineering and science subjects. Furthermore, the effects of partnerships between universities in Afghanistan with universities in the developed world will be investigated and reported as such partnerships have contributed to the areas of computer science and IT.

\section{History of computer science and IT courses at higher education institutions in Afghanistan}

The Afghan government has realised the importance of ICT and hence converted the ministry of communications to the ministry of communications and IT. Short-term training in ICT tools has been provided for junior and mid-level managers at many governmental and non-governmental organisations for the past six or seven years in order to overcome the shortage of ICT professionals in the immediate future. However, such training programmes have not been organised in a uniform and cohesive way to alleviate the long-term gap of the ICT professionals in the country. Regrettably, the progress has been limited despite of huge amount of investment by the international community in ICT related projects. However, the first national conference which was organised by the ministry of communications and United National development Program (UNDP) was held in Kabul in 2006 [4].

It is unfortunate that the Afghan government has not considered integrating ICT within the mainstream education system in the country. ICT can provide unique opportunity for both academics and students to have access to a rich library of information, free of charge via the internet.

An integrated approach is needed by the Afghan government and international community to introduce computers and internet access into the learning environment in Afghanistan, such introduction will have a major effect on education system. As the learning resources such as fully stacked libraries and fully equipped computer laboratories are rare in the country, careful planning is required to prioritize the introduction of ICT into the mainstream education including higher education. 
While the world has changed dramatically in the past few decades and will continue to do so with an accelerating pace, the learning environment, i.e. the classroom has not changed but it will change in the near future. The education system in Afghanistan must follow its international counterparts by international norms into the education system. ICT can play a major role to achieve such objectives.

The first undergraduate programme on computer science was started at Kabul University (KU) in 1997 [5] and since the establishment of the new government in Afghanistan in 2002 many other computer science and IT courses have been introduced at Universities in the country. Many computer centres have been created at Kabul University and other higher education institutions in Kabul and other major cities. Though, the there is little or no collaboration between the various computer centres and their sponsors.

The list public universities offering computer science and IT courses are as follows:

\author{
a. In the Capital \\ Kabul University (KU) \\ Information and Communication Technology Institute (ICTI) \\ Kabul Polytechnic University (KPU) \\ University of Education
}

b. Provincial Universities

Balkh University (BU) in the north of the country

Nangarhar University (NU) in the east of the country

Kandahar (KU) and Sheikh Zahid Universities located in Khost (SZKU), in the south east and southern Afghanistan

and Herat University (HU) in western Afghanistan.

There are many private institutions which offer IT courses beside the above public universities in Afghanistan. 


\section{Reasons for success}

To the author's knowledge, the following factors are the main reasons for the success of computer science and IT courses in Afghanistan.

\subsection{New Technologies such as computers and wireless communications}

Computer technology and mobile telephones have recently been introduced to the country and the majority of youngsters in the country are fascinated by these technologies and try to incorporate it into their daily life. Computer science and IT courses are popular courses after medicine and engineering and attract talented candidates at universities across the country. Some students, who are unable to get admission to public universities, learn computer and ICT skills at private institutions; which increase their chances of finding well paid jobs at the government or non-governmental organisations. The establishment of communication and internet companies and other development in the area of electronic communication has a major effect by promoting ICT in the country. According to the latest information from ministry of communications and IT, the number of companies which provide communications and IT services are in excess of thirty three.

\subsection{Better employment opportunities}

The international organisations working in Afghanistan usually hire a workforce that is computer literate; as a result, candidates with computer skills will have major advantages over other candidates applying for same positions at various UN agencies and other non-governmental organizations (NGO's). The jobs at international organisations are more rewarding compared to the jobs at the Afghan government or local companies.

\subsection{Donors willingness to invest in the labs}

Mysteriously, it has been very easy to persuade the donors to invest in computers and ICT equipment compared to equipment for traditional engineering and science subjects and thus, many new computer laboratories can be found at most higher education institutions. However, the lack of coherent IT policies and their applications specifically in sharing the learning resources such as text books, libraries and IT equipment amongst the Afghan universities are clearly evident. The Afghan government ought to address this issue.

\subsection{Young and enthusiastic academics}

Most of the experienced and qualified academics at higher education institutions in Afghanistan have either fled the country, retired or have been victims of the wars in the country. Those who stayed behind were isolated from the rest of the world and some of them have been involved in politics and regrettably 
politics was mixed with the education, which had a devastating effect on the whole education system in the country.

One of the major advantages of the computer science department at Kabul University is that the vast majority of the academics are young, enthusiastic and some of them may have some international experience too. Consequently, the majority of the academics are willing to enhance their knowledge and adapt new academic practices within. The constructive attitude of such academics had a positive effect and greatly improved the quality of education that they provide compared to the traditional science and engineering courses which has a long history within the universities in Afghanistan.

\subsection{Improvement of the higher education}

\section{The effect of academic partnerships between Afghan universities and universities in the developed world}

The Afghan government has realised the importance of training academics for computer science and IT, and other science and engineering subjects. Thus, have established partnerships with well established universities in the western world.

The aim of the program was to establish partnerships between the Afghan universities and universities in the developed world. The key objectives of this partnership were:

(a) Revision of curriculum in both theory and practice

(b) Faculty upgrading program

(c) Upgrading the libraries and laboratories

(d) Faculty and student exchange

(e) Joint research and publications.

A number of partnerships between Afghan universities and universities in the developed world have been established [3] and to the author's knowledge, the following three partnerships involve the training of Afghan lecturers for the computer science and IT sector:

a. KU and some other universities in Afghanistan with Technical University of Berlin, Germany [6]

b. KPU and University of Brighton, UK

c. Ningarhar University and San Diego State University (SDSU), USA.

A large of group of Afghans lecturers from the above three partnerships are due to finish their MSc programmes in 2009 and it is expected that the contribution of the new lecturers will further enhance the computer science and IT subjects in Afghanistan. 
The partnerships primarily cover engineering disciplines at Afghan universities; however, the progress at the universities in Kabul, i.e. KU and KPU has been limited for the following reasons:

1. Most of the senior academics including the chancellors, vice-chancellors, the deans and department heads possess the war time experience but have not been exposured to modern management practices. For that reason, they are resisting modern management practices and are unwilling to change.

2. The rule of law is very weak and there is little or no accountability.

3. The institution is a public university and is funded by the government but the Ministry of Higher Education does not have much control on the operation of such institutions.

4. All the senior managers do not have the vision or experience on how to run an educational institution at the present time.

5. The appointments of senior managers are not based on merit but managers are appointed by the authorities on the basis of their political affiliation or their ethnicity.

\section{Conclusions}

The relative progress of courses related to computer science and IT at the Universities in Afghanistan and reasons behind such progress has been highlighted in this paper. It is hoped that the Afghan government will learn lessons from such successes and extend the experience to improve science, engineering and technology courses at the educational institutions in the country. Further work is required to extend the benefits of this positive development to other subjects and make full use of ICT in other sectors. The recommendations are as follows;

1. In the present circumstances, ICT should be integrated into the core curriculum of mainstream education in Afghanistan, i.e. at primary and high school, college and university levels in the country;

2. ICT policies should be developed at the government and institutional levels; sound national policies are based upon government priorities and goals, which are associated with the present circumstances in Afghanistan. Policy strategies or approaches to achieving goals may differ, especially in regard to supporting ICT usage and research in higher education institutions Afghanistan.

National policies that positively impact on ICT adoption and expansion include those that:

a. promote access to IT skills and education for all;

b. improved network infrastructure in urban and rural areas; 
c. Encourage technological research and development.

Positive ICT policies and investments are clearly beneficial to higher education institutions, even though ICTs have not replaced classroom-based modes of learning or teaching. Undoubtedly, ICTs can provide greater access for different target learners, and have become vehicles for enriched pedagogical experiences, particularly for distance educators and learners separated by time and space.

3. Incorporating entrepreneurship in the curriculum, ICT can play a major role to achieve this objective;

4. Close collaborations and coordinated effort is required between various stake-holders that are contributing to the development in Afghanistan;

5. A plan should be developed to assess the impact of the present ICT and other projects in the country.

6. The necessary ICT training should be provided for the academics and administrators at the education and higher education institutions in the country. The training will be more productive and effective provided academics are committed and willing to learn, and change their attitude towards adapting the new practices. Otherwise, any significant progress to address this issue seems a distant possibility.

Acknowledgement

The authors would like to acknowledge the contribution of Mr. Ata M. Yari who is a senior advisor at the Ministry of communications and IT in Afghanistan, who has provided valuable information on the progress at communications and IT sector in Afghanistan. 


\section{Bibliography}

1. Samady, R. S., "Education and Afghan Society in the Twentieth Century,“ United Nations Educational Scientific and Cultural Organisation (UNESCO), November 2001. http://www.reliefweb.int/library/documents/2002/unesco-afg-nov01.pdf

2. Baha, B., "Engineering Education in Afghanistan," Proceedings of the 2003 WFEO/ASEE e- Conference. June 2003.

3. Baha, B, Z, Baha (2008) Technical Vocational and Engineering Education in Afghanistan, American Society of Engineering Education (ASEE) Conference, Philadelphia, USA, June 2008.

4. Ministry of Communications, "First National ICT Conference Afghanistan 2006 ", April 2006. http://www.ictconference.org.af/

5. Ministry of Higher Education, "International Conference on Information Technology for Higher Education in Afghanistan,“ June 2008. http://www.mohe.gov.af/?lang=en \&p=conferences \&nid=25

6. René Herlitz, R, "Qualification of lecturers for the establishment of computer science faculties at Afghan Universities," Assessing the contribution of ICT to Development Goals, Dubai, United Arab Emirates, May 2009.

http://www.ifip.dsg.ae/Docs/FinalPDF/Practioner\%20Reports/ifip $70 \quad \% 20$ Rene $\% 20$ Herlitz.pdf 


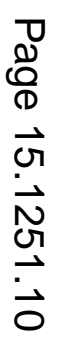

